\title{
DEVELOPMENT OF APPLICATION INSETS IN THE GARMENTS FOR PEOPLE WITH DISABILITIES
}

\author{
Gleb Pozilov-Nesmiyan', Natalya Suprun ${ }^{1 *}$, Tatyana Girna' \\ ${ }^{1}$ Kyiv National University of Technologies \& Design, Ukraine \\ Scientiflc paper \\ *e-mail: suprun.knutd@ukr.net \\ UDC: $687+646.4$
}

doi: $10.5937 /$ tekstind2001018P

Abstract: Composite application insets on the base of medical carbon fabric and needle-punched nonwoven web structures of different raw materials was elaborated for use in the garments for people with disabilities. The influence of structure and raw material composition of obtained composites on the processes of moisture absorption and drying was determined.

Keywords: nonwoven, textile composites for medical application, carbon fabric, moisture content, drying kinetics.

\section{RAZVOJ UMETAKA U ODEĆI ZA LJUDE SA INVALIDITETOM}

Apstrakt: Kompozitni umetci na bazi medicinskog karbonske tkanine i netkane mrežne strukture od različitih sirovina razmotren je za primenu u odeći za ljude sa invaliditetom. Uticaj strukture i sirovinskog sastava materijala dobijenih kompozita na proces apsorpcije vlage i sušenja je utvrđen.

Ključne reči: netkani, tekstilni kompoziti za medicinsku upotrebu, karbonska tkanina, sadržaj vlažnosti, kinetika sušenja.

\section{INTRODUCTION}

One in seven people worldwide experience a disability, and with the ageing population, as well as an increase in chronic conditions, this number continues to rise [1]. Significant parts of the disabled people are those who use the wheelchair. Their quality of life can be improved by use of specially designed functional clothes. A spinal cord injury causes temporary or permanent changes in the function of organism. A person, who moves with a wheelchair spend most of the time in a fixed sitting position. A special danger for them is the possibility of forming of pressure ulcers [2] in places where the bones extend close to the surface of the skin (Fig.1).

The treatment and care of pressure ulcers is high in cost, long in time and needs careful drying of wound and protection against ingress of bacterial flora. For this purpose, antiseptic porous wound

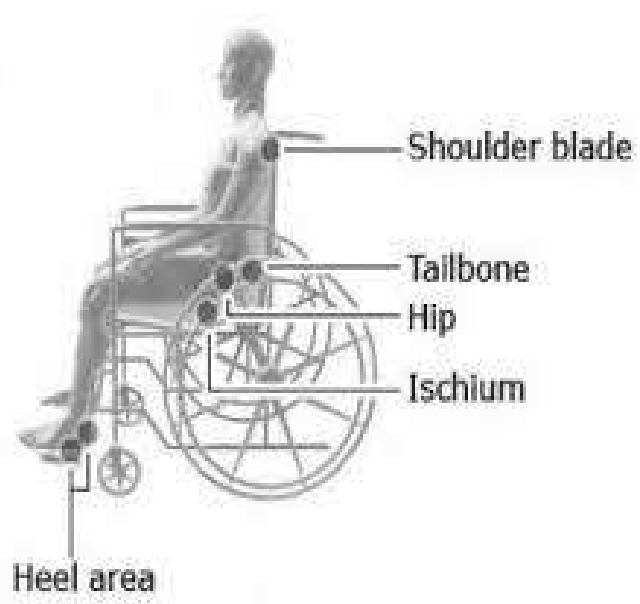

Figure 1: Body areas with a risk of pressure ulcers

dressings are used, which provide the evacuation of moisture from the ulcer surface and access oxygen to it. Effective for this purpose is the use of wound 
dressings based on active fibrous carbon sorbents [3]. Due to the developed sorption surface they are a convenient matrix for the immobilization of various medicinal substances, provide rapid absorption of wound exudate, keep in their structure moisture and drugs, clean and disinfect wounds. But along with all the advantages of this dressing, one of their disadvantages, noted by many practitioners is that the carbon fabric too quickly absorbs and gives off the moisture, which leads to quick drying of the wound and sticking of the bandage.

To reduce this negative factor, we propose to connect by the method of heat-duplication the carbon fabric with nonwoven web structures, which will act in this composite as accumulative volume. Such wound dressings can be located as application insets on the undergarments in the places of prolonged contact of the body with a solid surface of wheelchair, bed, etc. Their fixation on the inside of the linen can be done in different ways - by placing them in special open "pockets", using thin velcro textile fasteners, by applying a sticky layer, etc.

The type of the textile base is one of the important components of such systems and their proper choice will determine the properties of the multilayer material. The purpose of this work is a comparative analysis of the moisture-transport properties of composite wound dressings obtained with the use of medical carbon fabric and needle-punched nonwoven web structures of different raw materials.

\section{EXPERIMENTAL}

\subsection{Materials}

Needle-punched nonwoven web structures of different raw material composition and thickness for cumulative layer in multilayer composites were obtained on the technological equipment in Kyiv national university of technologies and design (Fig.2). Their main components were natural flax or cotton fibers, which have high sorption properties and are allowed to be used in medical practice. To improve the technological and operational properties of nonwovens, polyester and polyurethane fibers were added to their composition. Technological operations of production of non-woven web structures on the example of composition: Linen $-50 \%, \mathrm{PA}-30 \%, \mathrm{PE}-20 \%$ are shown in Fig. 2,a; obtained composite material with the upper layer of carbon fabric is shown in Fig.2,b.

To provide bactericidal properties non-woven webs were nano-treated according to the developed eco-friendly method [4] with aqueous solutions of silver nitrate using glucose as a reducing agent were made. As the first layer of composite application material, which directly contact with an ulcer or wound, we used activated carbon material of medical purpose of domestic production. Two-layer and three-layer composite application materials were obtained by thermally duplicating one layer (package No. 1) or two layers (package No. 2) of nonwoven web structures of the corresponding raw material composition with carbon fabric using an adhesive mesh of thermo-

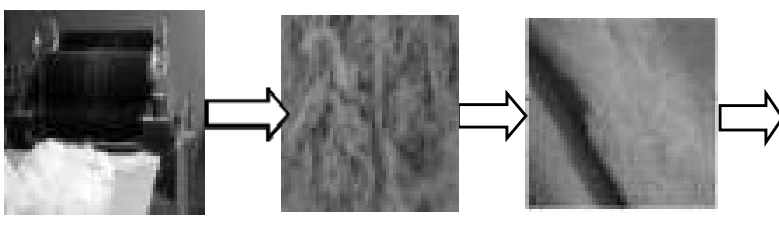

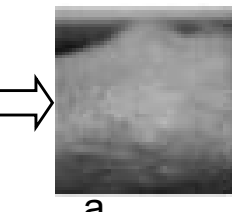

a

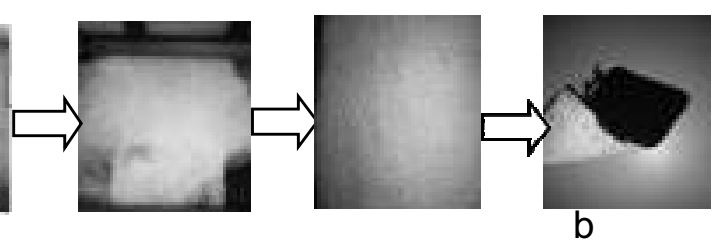

b

Figure 2: Technological operations of production of non-woven web structures (a); composite material (b)

Table 1: Structural characteristic of nonwoven webs

\begin{tabular}{|c|l|c|c|c|c|}
\hline \multirow{2}{*}{$\begin{array}{c}\text { Sample } \\
\text { number }\end{array}$} & Raw material composition, $\%$ & \multirow{2}{*}{$\begin{array}{c}\text { Thickness, } \\
\mathrm{mm}\end{array}$} & \multicolumn{3}{|c|}{ Surface density, g/m ${ }^{2}$} \\
\cline { 4 - 6 } & & 1,2 & 138 & 296 & 369 \\
\hline 1 & Linen -50; PE -50 & 1,1 & 194 & 193 & 385 \\
\hline 2 & Linen - 70; PE- 30 & 0,7 & 183 & 231 & 353 \\
\hline 3 & Linen - 50; PA - 30; PE - 20 & 0,7 & 169 & 335 & 410 \\
\hline 4 & Cotton -50; PE - 50 & 0,5 & 185 & 205 & 307 \\
\hline 5 & Cotton -70; PE - 30 & 0,5 & 191 & 303 & 379 \\
\hline 6 & Cotton -50; PA - 30; Lycra - 20 & 0,5 & 161 & & \\
\hline 7 & Carbon fiber 100 & & & \\
\hline
\end{tabular}


plastic polymer having two-sided adhesive capacity. Further increase in the number of layers seemed inappropriate due to the significant rise of stiffness of the resulting composite, which negatively affects the tactile comfort in use. The structural characteristics of obtained materials are presented in Table 1.

\subsection{Research Methods}

The surface density of the webs was determined in accordance with Ukrainian Standard 3811-72; the thickness of the webs - ISO 5084: 2004. To compare the influence of different raw material composition and structure of two- and three-layer composite materials on their ability to adsorb and desorb liquid moisture, was used the determination of water absorption (according to Ukrainian Standard 3816-81 ISO 811-81, moisture absorption rate, as well as moisture desorption during drying at room temperature.

\section{RESULTS AND DISCUSSION}

The moisture capacity of materials for medical purposes is one of the most important indicator of their quality. Increasing the value of water uptake means an increase in the sorption capacity, which, in turn, extends the lifetime of the comfortable use and reduces the required number of replacements. According to the obtained data (Fig.3) all developed composite materials have high water absorption properties.
Duplication of carbon fabric with non-woven webs leads to an increase in moisture content for both two-layer and three-layer materials. This is most evident for composites with linen fibers - the values of $\mathrm{W}, \%$ in the two-layer packages increase approximately 1.8 times compared to the original carbon fabric. The addition of one more non-woven layer proportionally increases the moisture content of the composite materials. It is most noticeable for samples No. 4, 5 of package No. 2 - the values of $W$ increase more than twice.

The ability of the obtained composite materials to absorb and evaporate moisture over time was characterized by curves of wetting and drying (Fig.4).

According to modern views on the wounds and ulcers, application materials for their care must have a prolonged ability both to sorbs the exudate to full moisture saturation, and also to desorption while drying under normal environmental conditions. Duplication of carbon fabric with non-woven webs contributes to the success of both processes, and increasing the thickness of the non-woven layer slows them down over time. Taking to consideration the bactericidal ability of all the components used, the complex of the given properties of developed composite textile materials meet the functional requirements of modern sorption-application products, which allows to expect a positive effect from their use as functional inserts in the body products in places of contact with pressure ulcers.

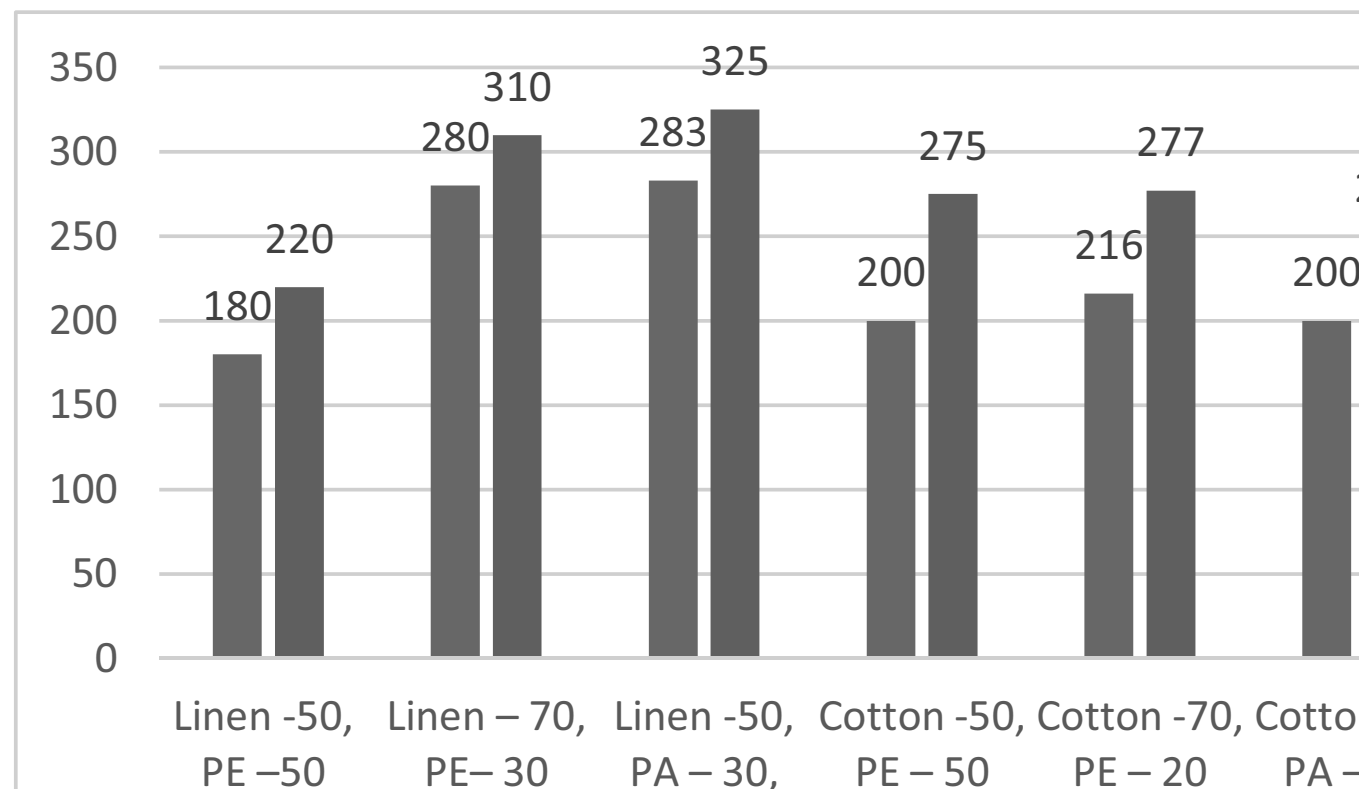

Figure 3: Water sorption of composite materials, W, $\%$ 

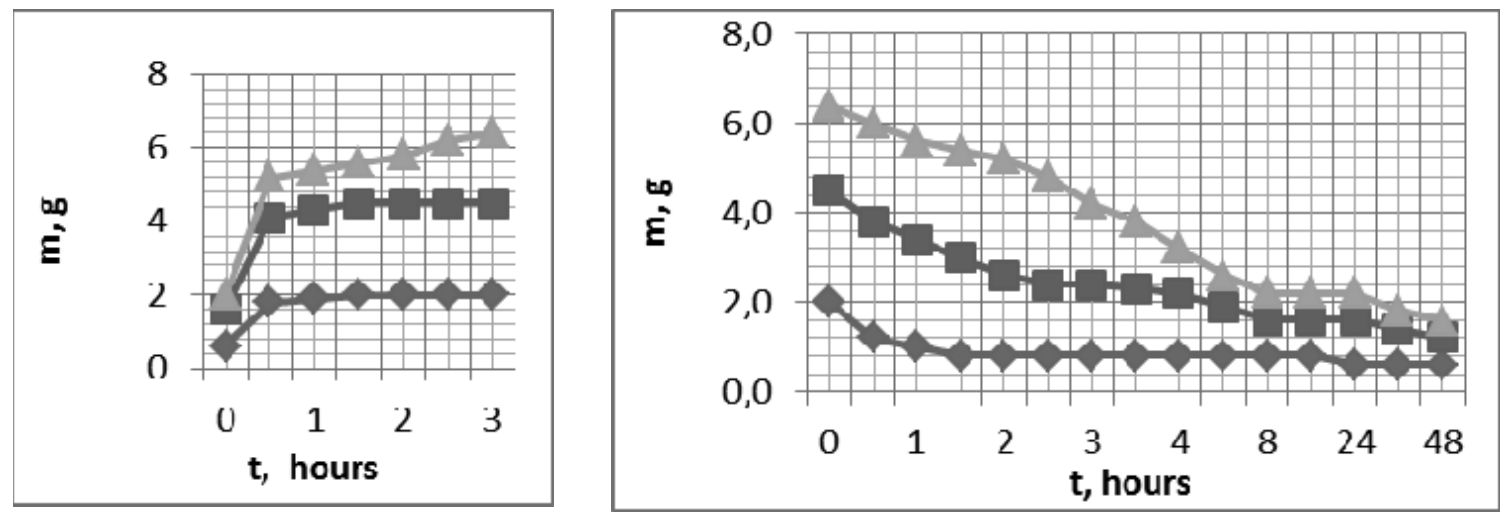

Linen $-50 \%$, PE $-50 \%$
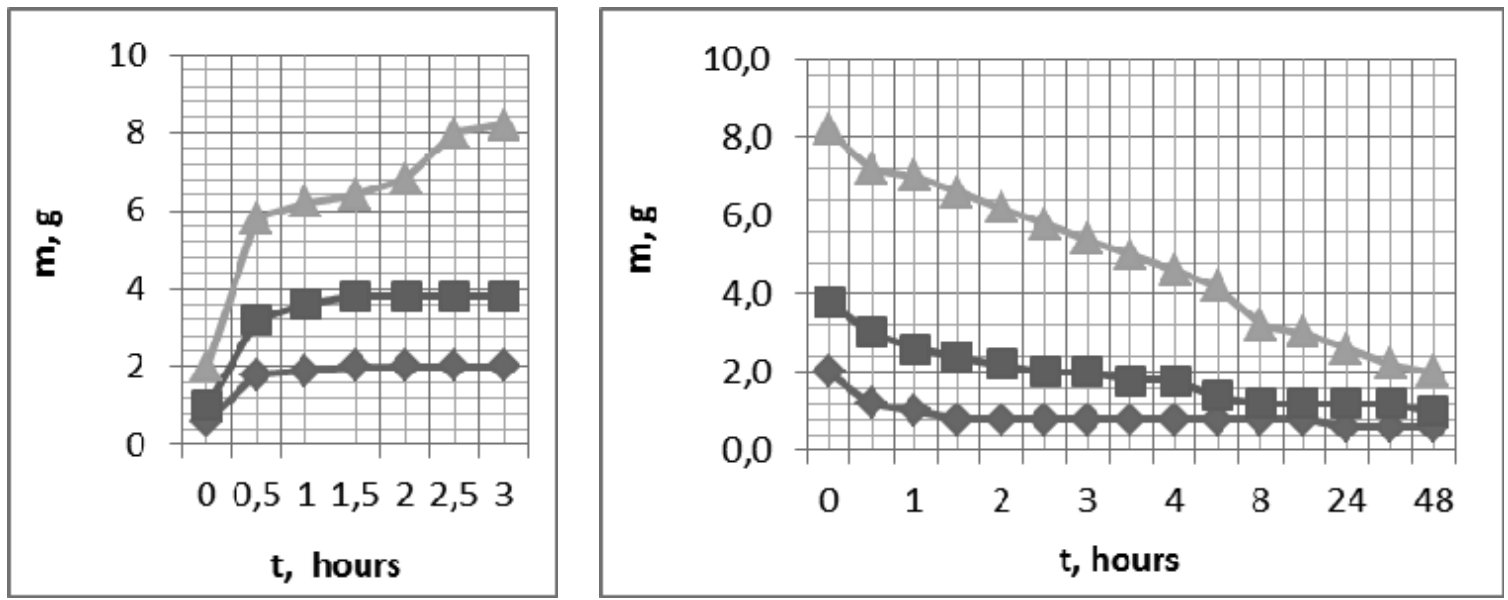

Linen $-70 \%$, PE -30\%
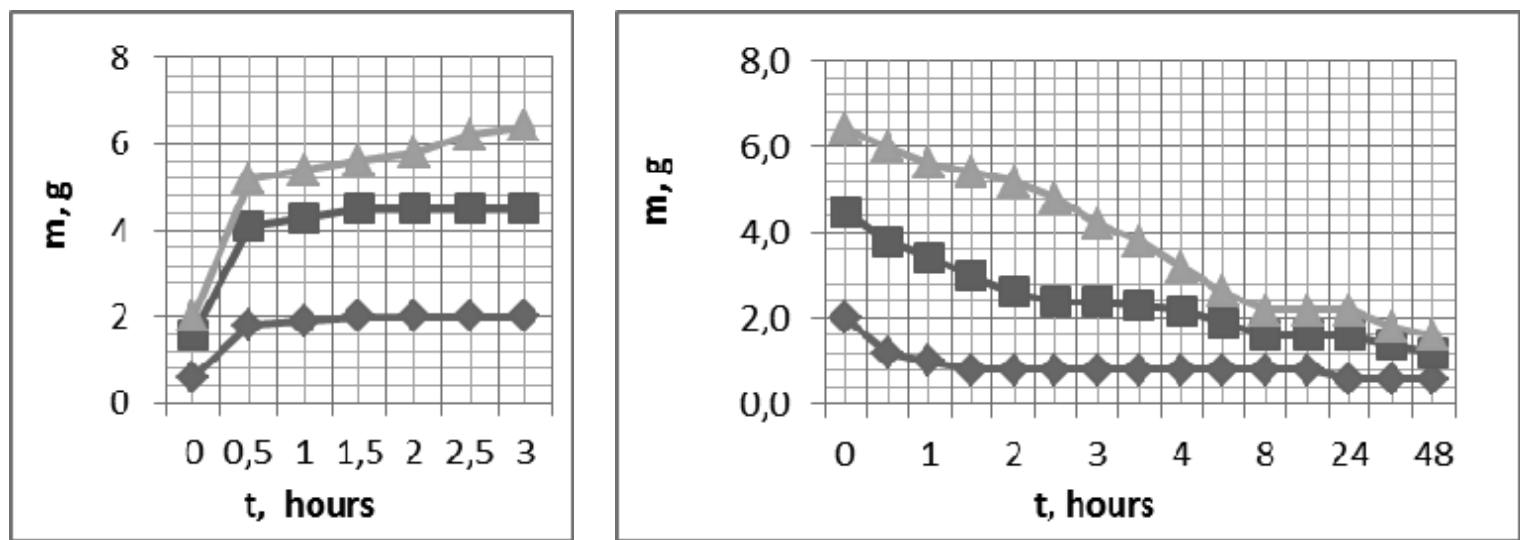

Linen - 50\%,PA - 30\%,PE - 20\%

Figure 4: Changing of the samples weight during wetting (a) and drying (b)

\section{CONCLUSIONS}

Investigation of the influence of the raw material composition and structure of the nonwoven base in textile composite materials with carbon fabric as the upper layer on the processes of moisture absorption and drying have shown the possibility of regulating these processes. It has been found that connection of carbon fabric with non-woven needle-punched webs based on linen fibers provide the highest moisture content and slowest rate of moisture sorption and desorption, which facilitates the comfortable use of applique inserts in therapeutic and prophylactic sewing products in contact areas. 


\section{REFERENCES}

[1] World Health Organization. Disability and HealthFact Sheet. Geneva: World Health Organization, 2016.

[2] Stephens M., Bartley C.A. (2018). Understanding the association between pressure ulcers and sitting in adults what does it mean for me and my carers? Seating guidelines for people, carers and health \& social care professionals. Journal of Tissue Viability. 27, 59-73.
[3] Scheer H.S., Kaiser M., Zingg U. (2017). Results of directly applied activated carbon cloth in chronic wounds: a preliminary study 2017. I Wound Care. 26(8), 476-481.

[4] Suprun N.P., Brichka S. Ya., Litvinova O. I. (2017). Development and investigation of nonwoven wound dressings with antimicrobial properties on the basis of natural fibers. Vlákna a textile. 24(2), 3-10.

Rad primljen: 10.02.2020.

Rad prihvaćen: 28.02.2020. 